\title{
Corporate Governance: Mechanisms for Control and Alignment of Interests of Participants of Corporate Relations in the Transitive Economy
}

\section{Elena Eugenievna Tarando}

Saint-Petersburg State University, Faculty of Sociology, Department of Economic Sociology Email: elena.tarando@mail.ru

\section{Alexander Fedoseevich Borisov}

Saint-Petersburg State University, Faculty of Sociology, Department of social management and planning Email: borisov-af@mail.ru

\section{Inessa Yurievna Chelenkova}

Saint-Petersburg State University, Faculty of Sociology, Department of social management and planning Email: inessa_2407@mail.ru

\section{Nikolay Alexandrovich Pruel}

Saint-Petersburg State University, Faculty of Sociology, Department of social management and planning Email: pruijel@inbox.ru

\section{Mikhail Vladimirovich Sinyutin}

Saint-Petersburg State University, Faculty of Sociology, Department of Economic Sociology Email: sinewtin@yandex.ru

\author{
Doi:10.5901/mjss.2015.v6n4s4p118
}

Abstract

The article presents findings of an empiric sociological survey of corporate governance at middle-sized industrial corporations in Russia. Evaluation of the effect of a market, federal law, internal corporate standards, and actions of corporate governance bodies on control and alignment of interests of participants of corporate governance has been given. Based on a contentanalysis technique, which was applied to annual statements of middle-sized industrial corporations, formation of an insider model of corporate governance, approval of major owners at the corporate governance bodies, who are usually chairpersons of the Board of Directors and general managers of such companies, has been confirmed. A degree of focus on interaction with main stakeholder groups, such as consumers, customers, suppliers, personnel, partners and banks, and governmental authorities was discovered in the course of survey. According to the survey, the corporate law is the primary regulator of corporate relations, internal corporate standards and rules are hardly demanded, and non-formal relations with representatives of the governmental structures take an important place, and behaviour motivation is defined by rational profit motives. Activity of corporate governance bodies is formalized, ensuring solutions for matters of procedure. Evaluation of the corporate governance at middle-sized industrial corporations was obtained by way of a questionnaire survey. The level of agreement of interests of their parties was discovered. This article presents a detailed analysis of the matter of conflicts of participants of corporate relations, ways of overcoming such conflicts, based on defining priorities in fulfilling interests of participants of corporate governance. The respondents measure the level of corporate governance at middle-sized corporations as satisfactory and corresponding to interests of main participants of corporate relations.

Keywords: corporate governance, transitive economy, middle-sized corporation, stakeholder, corporate standards, corporate governance bodies, interests of subjects and participants of corporate relations.

\section{Introduction}

Transition of the Russian economy to market relations and incorporation of Russian companies in the global network of economic interconnections created objective conditions for forming and developing corporate governance. A Russian 
model of corporate governance that is based on Western templates is constantly being revised, with view to specifics of the Russian corporate law and current practices of corporate relations at the Russian market. A variety of social groups (shareholders, managers, personnel, partners, creditors, competitors, etc.) with various needs and interests participates in corporate interactions; there is a diversity of behavioral patterns, i.e. from a conflict of interests to long-term trustful relations. In this regard, mechanisms of control and agreement that ensure effective cooperation of participants of corporate relations, with view to their corporate interests, are one of the most relevant matters for investigation. An unstable model of corporate governance functions in the Russian conditions, and standards and rules of such model are still in the process of formation, including compromising and contradictory ones that complicate control and agreement of interests of subjects and participants of corporate relations.

Fulfilment of this survey at middle-sized regional industrial corporation is a specific of this survey. Such surveys were not popular enough until recently. Middle-sized Russian corporations were most often considered from the point of a mechanism of merging such corporations over the course of market monopolization by large corporations. Governmental structures did not pay enough attention to corporations of this type, which affected repeatedly the process of adoption of laws that ignored their interests, complicated industry-related and regional activity of middle-sized industrial corporations. Although, things have been changing for the last few years. It is associated with a high adaptability, expressed by such companies and ensuring survival and high rates of growth in the conditions of an unsteady internal and external environment. Middle-sized business demonstrated high rates of growth in a number of segments of the market economy. Moreover, activity of middle-sized corporations depends, because of limited resources, on the choice of a certain development alternative, priority and nature of relations with counterparties, established relations with partners, personnel, management, and shareholders.

This article aims at analyzing mechanisms for control and agreement of interests of subjects and participants of corporate governance at middle-sized Russian industrial corporations.

This analysis allows for defining ways of further improvement of such mechanisms to ensure long-term steady and successful development of middle-sized regional industrial corporations.

\section{Literature Review}

The matter of corporate governance is exploited enough in the scientific literature. A variety of articles on this matter and a rather great number of specialized magazines that publish articles devoted to various aspects of the corporate governance (Corporate Governance: An International Review, Annual Corporate Governance Review, Corporate Governance and Sociology or Psychology, etc.) are the evidence of importance of this matter.

Along with traditional and purely economic topics for analysis of the corporate governance, associated with interconnection between the specifics of financial flows and company performance (Al-Rassas and Kamardin, 2015; Prison and Turnbull, 2015; Rossi et al., 2015), interconnection between the governance structure and capital structure of corporations (Alves et al., 2015; Ducassy and Montandrau, 2015; Drago et al., 2015; Bocharova, 2014), interrelations of corporations and the state (Col and Errunza, 2015; Nhung and Okuda, 2015), issues of risk minimizing for investors (Chen et al., 2015; Tan and Ding, 2015), analysis of interaction of market and non-market mechanisms in the system of corporate governance functioning (Du et al., 2014), issues of increasing corporate governance quality in the conditions of imperfect markets, including in the conditions of information asymmetry (Elbadry et al., 2015). Works devoted to analysis of participation of stakeholders in the corporate governance system, in particular determinacy and feasibility of their interests (van Essen et al., 2015; Bruno, 2015; Uysal and Tsetsura, 2015; Ayuso et al., 2014; Lai and Chen, 2014) represent a special stratum of literature. At the moment, research of the effect of nepotism on corporate governance specifics also became relevant (Rees and Rodionova, 2015; Schmid et al., 2015).

The modern stage of research of corporate governance specifics is characterized by scientists' attention to its social aspects. Thus, issues, such as increasing the level of control in the corporate governance system (Rubtsova, 2011; Rubtsova, 2007; Rubtsova et al., 2015), professional structure in the corporate governance system (Malinina et al., 2015; Rubtsova et al., 2015), governance specifics at non-economic organizations, based on the principles of corporate governance (Pfang, 2015), are being worked out. Topics involving the effect of trust on the corporate governance system (Spraggon and Bodolica, 2015; Kapustkina et al., 2008) or the role of a woman in such system (Bianco et al., 2015; Sabatier, 2015, Kapustkina, 2008) are quite popular now. Papers analyzing the effect of the corporate governance and corporation's activity on various aspects of people's life, and food culture in particular began to appear (Veselov, 2015).

Works devoted to studying establishment of interconnections of interests and interrelations between certain groups of participants in corporate governance in the global practice (Lin et al., 2015; Albu and Mateesku, 2015; Findlay, 2014) deserve special attention. There are articles available, where various aspects of the Russian corporate governance 
practices are studied (Braendle, 2015; Thibeault et al., 2015; Fox, 2014; Tarando et al., 2015).

At the same time, the topics of functioning and development of middle-sized business in the Russian economy started to come out of the periphery of attention of scientists, research agencies and centers. Projects and surveys that are prepared by the Expert RA rating agency are of a great importance. These include: 'Middle-sized business: governance and financing technologies: analyzing Russian and foreign experience - 2011', 'Leaders of middle-sized business/Conference ARS dated March 21, 2013'. Challenges that the middle-sized business faces such as financing, administrative pressure, shortage of highly qualified personnel, etc. are analyzed in such studies. It is important that a criterion for referring any company to the middle-sized business has been established. Annual profit of the company in the amount from $300 \mathrm{mln}$. up to $5 \mathrm{bln}$. Rubles is the criterion (Leaders of middle-sized business: consumer orientation, 2013). Two behavioral models of middle-sized Russian companies on the verge and in the course of 2008-2009 economic crisis are studied. The following has been marked out: successful middle-sized companies with their quick growth, based on applying the administrative resource at a regional level, and successful middle-sized firms that expanded their business, while relying on market factors. Forms of opportunistic behavior of managers and owners of Russian companies were analyzed and recommendations with the focus on support of the effective middle-sized business were compiled (Yakovlev, Simachev et al., 2009). The effect of corporate governance on strategy development, loaning conditions and conditions of other processes that are going on at middle-sized corporations are detailed in certain publications (Belikov, Verbitskii et al., 2007; Verbitskii, 2014).

Disclosing interests and causes of actions are the primary topic in studying mechanisms for control and agreement of interests of subjects and participants of corporate governance. Multiple theories, dealing with interests of different groups in the business area, are specified (Norman, Hit, 2006), causes of actions and opportunism manifestation in subjects of the corporate governance and prevention of such manifestations, based on legal regulations, contracts, measures to minimize various transaction expenses, accounting forms of motivated behavior and value orientations are discovered (Williamson, 1996), interests of primary groups of subjects and participants of corporate governance are analyzed, according to their status positions (Vesnin, Kadifov, 2013; Dementieva, 2011), and factors, determining agreement of interests of participants of corporate governance, are studied in works by domestic and foreign authors. These include: use of techniques for satisfying interests of the participants of corporate relations that are most important for the corporation (Mitchell, Agle et al. 1997; Tikhonova, 2012); drastic rebuilding of governance structure and governance mechanisms at corporations (Kleiner, 2011).

Internal and external mechanisms for control and agreement of interests of participants of corporate relations are discovered, based on a comparative analysis of Russian and foreign expertise in applied research (Radygin, 2007; Radygin, 2009), reports of the National council for corporate governance (National report on corporate governance, 2014). They point out that improvement trends for corporate governance bodies, such as ensuring observance of rights of shareholders, monitoring the management, cooperation of participants of corporate governance, dependence of corporate governance body functions on the completeness and flexibility of internal corporate documents are typical for the internal mechanisms. External mechanisms are analyzed on the basis of the accumulated experience in merging, take-over and splitting in the Russian industry (Briachak, 2010; Yakovlev, Simachev, Danilov, 2010), theoretic and empiric studies, justifying the effect of corporate law and corporate culture (Dolan, Garcia, 2008). The authors come to the conclusion that the established corporate governance mechanisms do not provide for any social interaction balance for participants of corporate relations. The following reasons are marked out: a formalized nature of activity of corporate governance bodies; insufficient relevance of internal documents, in particular code of corporate governance; opportunism and misjudgment of managers, leading to ineffective transactions; controversy of legal regulations, weak judicial protection, and low business culture and ethics.

Russian scientists associate one of the basic reasons for insufficient functioning of the corporate governance mechanisms with an unsteady development of the Russian model of corporate governance (Dimov, 2012; Ivanova, 2012). In the conditions of developing transitive economy and foreign political stress, the Russian model of corporate governance is systematically exposed to corrections by means of adopting laws and regulations to respond to challenges of the unsteady external and internal situation in the society (Ustyuzhanina, Evsyukov et al., 2010). Incorporated corporate governance standards and values are often an obstacle for some subjects and a stimulus for others, and they lead to acute social conflicts, destabilization and instability of the relations. In order to avoid any controversies in corporate governance development, S. Kirdina offered to consider, according to a theory of institutional matrix (Kirdina, 2005), historically stable and constantly reproducing basic social relations that are typical of the Russian society. Moreover, the interaction between subjects and participants of corporate governance takes place according to the mechanism of compromising standards. V. Polterovich called them 'institutional traps', as long as they are incorporated in the corporate behavior, while shaping the interaction that is far from the desirable one (Polterovich, 2009). We assumed 
in our works that there is an institutional insufficiency of the corporate governance as an ongoing controversy between the need of a corporate standard that corresponds to the interests of participants of corporate governance and possibilities for implementing such standard in the corporate governance practice.

Therefore, Russian scientists face a task of orientation on studying mechanisms that responded properly to timedependent challenges, introduced systematic changes in the corporate governance, with view to the developmental specifics of the Russian society.

\section{Survey Overview}

Our empiric survey aims at determining the established level of corporate governance at industrial corporations of the region, and effect of internal and external mechanisms on securing balance of interests of participants of corporate governance.

This empiric social survey was done on the basis of industrial corporations of the Tambov Region, which were selected according to the criterion established by the Expert RA Rating Agency. Their annual revenue ranges from 350 $\mathrm{mln}$. up to $5 \mathrm{bln}$. rubles. Accordingly, Pigment LLC, specializing in production of high-technology chemical product; Electropribor JSC, specializing in production of instrumentation and navigation equipment for aviation engineering; Tabovmash JSC, specializing in production of collective and individual protection equipment; and Milorem Michurinsk Locomotive Repair Works JSC, specializing in depot repair of locomotives and manufacture of spare parts, were included in the selection for further studying.

Content-analysis techniques and questionnaire survey of participants of corporate relations were used in the survey.

2013 annual statements of the said companies were used as a text material for the content analysis. The choice of annual statements is justified by the fact that the contents of such reports can be referred to a specific period of time, and structure of the annual statement comprises sections that can be compared. This allows us to use categories that have common meaning for each corporation. As long as annual statements are short, the content analysis is of frontal nature, while the contents are studied to the fullest extent. 23 conceptual and thematic categories, 38 sub-categories, and over 1,200 items of analysis were distinguished; and the meaning content of the items of analysis was evaluated (as positive, negative or neutral) in the course of the content analysis. A word or conceptual expression that is recorded in a contentanalysis form for each corporation was a unit of measure of the analysis. Data were processed and grouped, using the SPSS 15 program, and were presented for analysis in the form of tables and figures.

One primary and two secondary hypotheses were made in the course of survey. The primary hypothesis stated the following: provided a mechanism of control and agreement of interests of subjects and participants of corporate governance is effective, it ensures a high level of satisfaction with the corporate governance as a system of social interactions.

Secondary hypotheses were the following:

1. Provided internal and external mechanisms of interactions ensure agreement of interests of subjects and participants of corporate governance, their social interactions are characterized by trust, responsibility and fairness.

2. Provided interactions between subjects and participants of corporate governance take place in the conditions of institutional insufficiency of the corporate governance, interests of some of them are satisfied with infringement of interests of others.

Based on the questionnaire survey of subjects and participants of corporate governance, findings of the content analysis were verified, and conditions for improving the mechanisms for agreement of interests of subjects and participants of corporate governance were defined. Total 254 respondents were questioned at four companies, governmental bodies, non-governmental and other organizations. The questionnaire survey was performed on the basis of a target sample. A respondent's status in the structure of corporate relations, i.e. manager, shareholder, hired labor, representative of the governmental authority, or other participants of corporate relations (representatives of banks, nongovernmental organizations, partners, counterparties, or mass media), was the principal controlled parameter. For assuring data correctness, the above categories of the participants of corporate relations are represented in an equal proportion in the sample. A questionnaire comprised 23 basic items and possible answers for their further coding and computer-assisted processing. The questionnaire included open and closed questions. Nominal and matrix scales, ranging indexes and indicators were used for measurements.

The impact of formal and non-formal regulations on the formation of corporate governance at the middle-sized corporations of the region was clarified in the course of the survey. Factors that complicate agreement of interests of 
participants of corporate relations were defined. A level of satisfaction of expectations of participants of corporate relations at the middle-sized industrial corporations of the region was defined. Sources of conflict of interests between participants of corporate relations were shown. Conditions for improving agreement of interests of subjects and participants of corporate governance were determined.

\section{Middle-sized Corporations in the Conditions of Transitive Economy}

Information about the activity of the middle-sized corporations in the conditions of a non-determined, unsteady and controversial external environment that is associated with risks was collected, based on the content analysis. The corporations exhibit different attitude to the risks, which is confirmed by their semantic meaning. A social and political risk is valued as 'stable', industrial as 'acceptable'; regional and environmental risks are 'insignificant' for the corporations; inflation risk remains 'foreseen'; and currency risks are perceived as 'controlled'. A financial risk remains 'dangerous' for the corporations; and 'complicated' with a legal risk. Most financial risks (79.3\%) have an adverse effect on the corporate governance. Evaluation of the corporation's financial standing depends on the anticipations that are associated with the global market environment and troubles arising at the internal financial market. In relation to the latter, they are associated with corporation's expenses due to a short term, high rates and special conditions for credit reimbursement, and restricted banking information on the measures that involve interests of borrowers and creditors. Therefore, a strong negative attitude towards an institute of bank has established in the regional business community. The content analysis showed a high per cent of negative estimations of legal support of the corporate activity, i.e. $77.3 \%$. Corporations suffer real challenges due to incompetence in applying commercial and corporative legal standards; litigation unpredictability; ineffective judicial protection; imperfect and gap-bearing law; contradictions in legal rules; and complicated regulatory system. Statements of the joint-stock companies contain various examples of contradictions of industry-specific regulatory documentation and federal provisions, threatening disclosure of commercial secrets, and introducing the system of restrictive rules that complicate the commercial activity. Overall, the external environment is considered by the Tambov corporations as rather unfavorable for business processes, i.e. $56.5 \%$.

Nevertheless, the corporations estimate positively their position in the industry, i.e. $73.9 \%$. They characterize their position as 'stable', 'competitive', and 'having a satisfactory economic and financial standing.' These middle-sized corporations are 'cautiously optimistic' about their further development. The conditions for successful activity of the corporations are explained by internal factors.

1. Profit enhancement of the corporation is mainly due to technical re-equipping of the production, reduction in power costs, release of new product, and increase of labor efficiency. Equity to Total Assets and capital reserves increased; there is an ongoing process of financing agreements with research and development institutes and firms. Most companies exceed their planned expenses for technical re-equipment at the expense of reducing contributions to social programs. Thus, development of the middle-sized corporations is based on production modernization in the unfavorable conditions of self-financing and need of high-quality personnel, caused by an alternation of generations in labor collectives.

2. Strategic targets, governance and internal control at the corporation are subject to achieving production goals by $70.5 \%$. They can be described as 'modernization', 'technical re-equipping', 'mastery of new productions', 'growth in production and sales', 'environmental safety', 'product competitiveness', 'improved servicing', and 'profit improvement.' The issues of social planning and governance were discussed in $15.9 \%$ of the cases. They are defined by 'salary increase', 'better working conditions', 'better social security of the personnel', 'creating new jobs', and 'better living conditions'. 13.6\% of all information about strategic development of the corporations is dedicated to fulfilling corporate governance goals. Semantic meaning of this area of activity is disclosed in such discourses as 'increase in enterprise value', 'strengthening of business team', 'taking leading positions at Russian markets'. The development strategy of the regional industrial corporations is connected to management quality improvement, business process efficiency, and improvement of internal conditions for the steady development of the corporations. All these factors define the high level of adaptability of the regional corporations to difficult conditions of the 'new economy' and selection of their own development strategy. This means monopolization of the industrial market for certain types of product (Pigment LLC); development under the corporate umbrella of a powerful holding structure (Electropribor JSC); organizational and legal partnership relations with other companies (Milorem Michurinsk Locomotive Repair Works JSC); or product diversification and entry into a new sales market (Tabovmash JSC).

3. There is a change of corporate ownership structure going on at the corporations. Information about asset owners is still the most protected one. Nevertheless, we can make following conclusions, based on the 
analysis of open information about shareholding by the members of the Board of Directors, other affiliated parties and during execution of major transactions: the major share of stock belongs to a small group of shareholders; and controlling shareholders are usually at the head of corporate governance bodies. Every other of them is the Chairperson of the Board of Directors, and every forth of them is the Director General of a company. Thus, major holders of the company are involved directly in control over management's activity, which is indicative of an insider model of the corporate governance.

\section{Corporate Governance Bodies as a Tool of Control and Agreement of Interests of Participants of Corporate Relations}

Organizational structures of corporate governance are the primary internal mechanism, which aims at ensuring interests of main subjects to corporate governance. Evaluation of their activity was obtained in the course of survey. (Table 1)

Table 1. Evaluation of activity of corporate governance bodies by respondents

\begin{tabular}{|l|c|c|c|c|c|c|c|c|c|c|c|}
\hline & \multicolumn{3}{|c|}{5} & \multicolumn{3}{|c|}{4} & \multicolumn{2}{|c|}{3} & \multicolumn{2}{|c|}{2} & \multicolumn{2}{|c|}{ score } \\
\cline { 2 - 17 } & $*$ & $\%$ & $*$ & $\%$ & $*$ & $\%$ & $*$ & $\%$ & $*$ & $\%$ & \\
\hline 1. General Meeting of Shareholders & 25 & 10 & 86 & 34 & 104 & 41 & 36 & 14 & & & 3.2 \\
\hline 2. Board of Directors & 18 & 7 & 140 & 55 & 78 & 31 & 18 & 7 & & & 3.6 \\
\hline 3. Committees of the Board of Directors & & & 66 & 26 & 112 & 44 & 66 & 26 & 10 & 4 & 2.7 \\
\hline 4. Executive body & 8 & 3 & 104 & 41 & 114 & 45 & 25 & 10 & & & 3.4 \\
\hline 5. Corporative Secretary & 18 & 7 & 74 & 29 & 98 & 39 & 46 & 18 & 18 & 7 & 3.0 \\
\hline Average score (points) & & & & & & & & & & & 3.2 \\
\hline
\end{tabular}

The biggest scores were received by the Board of Directors (3.6), Executive body (3.4), General Meeting of Shareholders (3.2), lower scores were received by the Corporate Secretary (3.0) and Committees of the Board of Directors (2.7). In general, activity of the corporate governance bodies received a score of 3.2, using a five-point scale, which is indicative of the established satisfactory level of corporate governance at the companies. Positive trends are observed in the activity of the corporate governance bodies. This includes attention to strict adherence to provisions of the Law, while fulfilling corporate procedures, making decisions, approving major transactions and related-party transactions, and things that facilitate reduced conflicts of interests; introduction of a position of Corporate Secretary at half of the corporations; attempt of the Board of Directors to formulate a development strategy for the corporation, based on long-term planning; mastering corporate governance standards. The level of implementing such standards in the corporate relation practice corresponds to the needs and interests of owners, and it is evaluated positively, consequently, i.e. $66.2 \%$. Protecting the rights of ownership of shareholders, control of management's activity and satisfying interests of stakeholders are still the primary goal for the corporate governance bodies, acting on the basis of the insider model of corporate governance in any conditions.

According to the respondents, the level of protection of rights of ownership of shareholders is still quite stable. Interaction with minority shareholders is considered satisfactory. Control of top management's activity by the Board of Directors is estimated as average at the corporations. The respondents associate the efficiency of control of management's actions with a traditional set of techniques. These include: inspection by an external auditor (62\%), reports by top managers on fulfilment of resolutions of the Board of Directors (55\%), administrative actions towards the managers, based on financial statements (41\%); control of related transactions (28\%); disclosing information about managers' income (24\%). Control of management's activity is not restricted to administrative actions and sanctions. It is related to the need of consideration of their interests, based on implementation of material and moral incentive systems (34\%). Availability and disclosure of corporate information is one of principal conditions of ensuring control of management's actions.

Attitude of the corporation towards stakeholders varies from positive to negative. Intense competition makes companies dependent (100\%) on the consumer and purchase interests of the consumer. A positive orientation with regard to personnel $(81.6 \%)$ is manifested in developing a staff education and training system, in particular by training experts for the scheduled production. Suppliers are the third group of stakeholders in order of importance for the companies, and relations with the suppliers are established on a positive ground - $88.2 \%$. In order to prevent any expenses associated with selection of a mala fide supplier, there were proposals to perform a competitive selection of 
suppliers, and public online auctions. A positive motivation on long-term stable relations with partners was established $72.7 \%$. The corporations fear a disturbance of balance in partner relations, which leads to social conflicts and business losses. A negative attitude prevails in competitor relations - $60 \%$. The main threat appears in growth of cheap imported product at the industrial market, including a large share of pirated goods and falsifiers; limited scopes of the industrial market; growth and change of prices on raw materials, which lead to reduction in production volumes and profit. Banks and major shareholders are creditors of the industrial corporations. A short term, high interest and special credit reimbursement conditions formed a negative attitude towards the institute of bank in the business community - 88.9\%. An attitude towards governmental structures is ambiguous at the industrial companies. The corporations expect support of middle-sized business development, contractual procedures, tax privileges and non-intervention with their internal affairs from the government.

Overall, the level of interest balance of all participants of corporate relations is estimated by the respondents at $59.0 \%$ as 'satisfactory.' $31 \%$ consider it non-satisfactory, and just $10 \%$ - good. The scores in this publication confirm unresolved corporate conflicts for the regional corporations, which most often arise between the following three groups of parties: shareholders and top managers (59.0\%), management and personnel (55.0\%) and with competitors (41.0\%). Moreover, imbalance of corporate interactions with participants of corporate relations is indicative of a variable level of satisfaction by the parties of their expectations regarding the state of corporate governance. Answers regarding the 'level of satisfaction of expectations of primary participants of corporate relations according to certain indexes' were obtained, and a corporate governance level index from 0 to 200 was calculated. According to the query of the respondents, the highest satisfaction index is for consumers (147), governmental officials (140), shareholders (125) and partners (123). A lower index is for the personnel (102), trade unions (95), non-governmental organizations (94), and engineers (79). For example, if shareholders are satisfied with dividend payment (156), business partners with strengthening of their joint positions at the market (148), then non-governmental organizations are least satisfied with statutory compliance of social and environmental policy of the companies (88), and engineers are not satisfied with their life quality (60). The integral corporate governance index corresponds to an average level at the regional middle-sized corporations, i.e. 113.

\section{Basic Mechanisms for Agreement of Interests of Participants of Corporate Relations}

1. Agreement of interests of subjects and participants of corporate governance takes place according to a mechanism of considering their interest priorities. Answers of the respondents to questions 'Whose interests are fulfilled first of all, second of all, and lastly at the corporation' were obtained in the course of survey. The results were obtained, based on grouping differences of all positive choices (first and second choice) and negative choices (at last). They describe the social field of interests of participants of corporate relations, which are at least satisfied according to their importance. (Figure 1)
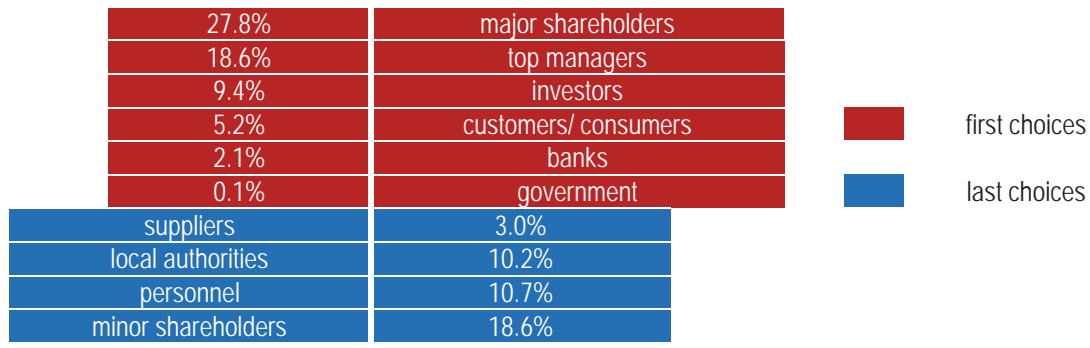

Figure 1. Priorities in fulfilment of interests of groups of participants of corporate governance (\%)

Questioning of the respondents confirmed that satisfaction of interests of major shareholders (27.8\%) and top managers $(18.6 \%)$ at the middle-sized companies is in the first place. The choice of the responders to the favor of investors (9.4\%), customers/consumers (5.2\%), banks $(2.1 \%)$ and government $(0.1 \%)$ confirms the dependence of the corporation on the position and policy of these participants of corporate relations at the market. The respondents make their choice 'at last' with regard to social groups, such as suppliers, local authorities and personnel that depend on the company (in terms of power, material and social support). In other words, a corporation may change it supplier (3.0\%), deny a request of a local authority (10.2\%), blandish its personnel (10.7\%), and ignore minor shareholders (18.6\%), while all these actions do 
not affect significantly the position of the corporation in general. Thus, a common trend in agreement of interests of participants of corporate relations was confirmed: first of all, satisfying shareholders' and top manager's interests and, lastly minority shareholders' and personnel's interests.

2. For the purpose of agreement of conflicting interests of participants of corporate relations, formal legal mechanisms are used, giving a varying degree of performance. Federal laws and legal relations outline the legal framework for corporations' activity. The degree of compliance of the federal laws to interests of participants of corporate relations is estimated as 'satisfactory' half the time (52\%). Just $1 / 3$ of the respondents (34\%) expressed their satisfaction with the 'good' degree of the legal regulations. Factors that affect adversely development, adoption and enforcement of legal regulations and rules were discovered in the course of our survey. These include: 1) specifics of adoption and enforcement of the legal regulations (different interpretation of the regulations, lobbying of the laws, controversy of the new and existing regulations, judicial errors in application of the regulations); 2) weakened control of compliance with the law (use of corruption schemes, impunity in case of failure to observe the provisions of the law, breach of control of internal document flow); 3) subjective factors (inadequate qualification, missing volitional powers of the manager, attitudes and established stereotypes of consciousness and behavior, ignored motivation of participants of corporate relations); 4) systemic disadvantages (introduced regulations contradict the historically established code of conduct, integrating corporate governance documents are missing).

3. Development of internal documents may detail legal regulations and affect the formation of the corporate governance system for a certain company. Overall, $83 \%$ of the respondents share this point of view. Compensational capabilities of the internal documents are underestimated today as regulators of intercorporate relations. The respondents believe the following is required to solve this task: 1) creating a complex of internal documents that comprise description of basic corporate governance principles and procedures; 2) systematizing corporate documents, using an incorporation technique; 3) introducing a complex of informational and technical means, aiming at collection, storing, analytical processing and presentation of information; 4) adopting their own code of corporate governance, ensuring a possibility of preventing any mismatch in the regulations, improving efficiency of social interactions.

4. Answers of the responders to the question: 'What structures would not companies turn to for help in protection of their rights and settlement of corporate conflicts?' are indicative of legal attitudes of participants of corporate relations of the middle-sized industrial corporations. It is telling that the participants of corporate relations do not seek help from criminal structures (83\%); they believe it is unlikely to get support from other entrepreneurs that have their own problems (59\%); obtaining support from mass media and non-governmental organizations does not also seem trustworthy (41\%). There is still a significant share of subjects to governance and shareholders that would not turn to the authorized representative for business rights (28\%), regional authorities (24\%), federal authorities (17\%) or arbitrage (17\%). Nevertheless, legal nihilism is not typical of participants of corporate relations. It became a common practice to address disputes at the arbitrage. A share of those who are going to resort neither to judicial authorities, nor to a special negotiator (mediator) is insignificant (17\% and 14\%, accordingly).

5. Informal regulations on agreement of interests of subjects and participants of corporate governance are important. Participants of corporate relations prefer to use informal communication with the authorities to solve their problems. The most effective are considered the following: personal contacts - $76 \%$, participation at elected governmental authorities - $48 \%$ and use of their membership in business associations - 34\%. 'Fair fulfilment of their obligations/ contracts to the government/ budget' option was chosen by $3 \%$. Satisfactory estimate of observance of business communication standards prevails among participants of corporate relations (59\%). These estimates may be explained by the motives for corporate behavior of the business community. The survey confirmed that the behavior of subjects and participants of corporate governance is overall determined by reasonable motives. These include: profit $(93,0 \%)$, control $(69,0 \%)$, benefit $(66,0 \%)$. The behavior is usually driven by such motives, as eagerness to take risk (45\%), strive for order (45\%), and commitment to business (38\%). There are the following opportunistic motives present in the corporate relations: self-interest, deception, lack of principles (24.0\%). Moral motives rarely define the behavior of participants of corporate relations. These include: justice (14.0\%), honesty $(7.0 \%)$, equality $(3.0 \%)$. There is not any altruism in the business. The behavior here may depend on force-majeure and actions according to the principle 'it is not personal'. Introduction of ethic regulations in the corporate relation practice is a challenging managerial issue, and solution to this task depends on wilful acceptance by the corporations of moral obligations to parties of corporate relations. 


\section{Conclusions}

Middle-sized industrial corporations of Tambov Region are the basis for industrial production development in the region. Their development is going on the grounds of modernizing production, while relying on self-financing, adapting flexibly to the market and choosing their development ways, such as monopolization of the industrial market for certain types of product, inclusion into holding structures, product specification or diversification. A change of corporate ownership structure, based on an insider model of corporate governance, and consolidation of positions of major shareholders takes place at the corporations. Every other of them is the Chairperson of the Board of Directors, and every forth of them is the Director General of a company.

General estimation of the corporate government that has established at the regional corporations was obtained in the course of opinion survey, and such estimation corresponds to an average level. A number of particular indexes are correlated with the estimation, in particular situation with protection of shareholders' ownership rights is overall stable, and the level of protection of minority shareholders' rights is estimated as satisfactory. According to the analysis of interactions of the corporations and participants of corporate relations, relations with consumers and the personnel are most important. There is a negative attitude at the corporations towards banks and competitors. An issue of conflicts was confirmed to be relevant for the corporations, and such conflicts arise most often between shareholders and top managers, management and personnel, and with competitors. Overall, the level of interest balance of subjects and participants of corporate relations is estimated as satisfactory. This estimation is confirmed by certain data, and, according to such data, participants of corporate relations exhibit a varying level of satisfaction of their anticipations as to corporate governance of the companies, i.e. from the highest level for consumers, governmental officials, shareholders and partners to the lowest level for the personnel, trade unions and non-governmental organizations, and engineers.

Details about mechanisms of control and agreement of interests of subjects and participants of corporate governance were obtained in the course of empiric survey, in particular. agreement of interests takes place on the ground of priority interest satisfaction, first of all of those of major shareholders, second of all of - top managers, while interests of suppliers, local authorities, personnel and minor shareholders are hardly considered.

Activity of corporate governance bodies is estimated as satisfactory. Activity of the Board of Directors primarily aims at fulfilling corporate procedures. A high share of negative estimates of legal support of the corporate activity was discovered, which is associated with imperfect law, problems of the law and inconsistency of provisions. There are not any codes of corporate governance and corporate ethics available at the corporations that would be their own.

The hypotheses were confirmed in the course of survey. The mechanism of control and agreement of interests of subjects and participants of corporate governance is established as satisfactory, which ensures an average level of satisfaction with the corporate governance as a system of social interactions. In the conditions of institutional insufficiency of the corporate governance, satisfaction of interest of some subjects and participants of corporate governance is done with infringement of interests of others.

The following recommendations were elaborated, based on the survey:

1. In order to improve corporate governance, it is necessary to overcome underestimation of importance of internal documents as regulators of intra-corporate relations. In this regard, the following is required: to create a complex of internal documents; to systematize corporate documents, using the incorporation method; to draft and adopt a Code of corporate governance; to implement a system of information support of corporate governance.

2. Improvement of corporate governance, based on contractual relations, involves recommendations associated with increasing demand of contractual regulators of social interactions, such as collective labor relations with the personnel; agreements with customers; suppliers; contracts with managers and other related parties.

3. For the purpose of improving social interactions of subjects and participants of corporate governance, it is necessary to improve moral and ethical standards and rules of conduct. In this regard, it is required to draft an ethic code of the corporation, implement social monitoring that ensures ongoing receipt of accurate and relevant information about the process of corporate culture formation.

This survey confirmed the necessity to take certain measures, aiming at increasing efficiency of corporate governance of the middle-sized industrial corporations of Tambov Region. These include: treating majority and minority shareholders equally; improving social status of engineer at the corporation; raising responsibility of members of corporate governance bodies; developing and applying various techniques that aim at improving agreement of interests of subjects to governance and participants of corporate relations; creating, on a regional level, a corporate governance training system. 


\section{References}

Albu N., Mateesku R.A. (2015). The relationship between entrepreneurship and corporate governance. The case of Romanian listed companies. Amfiteatru Economic, 17(38) (pp. 44-59)

Al-Rassas A.H., Kamardin H. (2015). Directors' independence, internal audit function, ownership concentration and earning quality in Malaysia. Asian Social Science, 11(15) (pp. 244-256)

Alves P., Couto E.B. et al. (2015). Board of directors' composition and capital structure. Research in International Business and Finance, (35) (pp. 1-32)

Ayuso S., Rodriguez M.A. et al. (2014). Maximazing stakeholders' interests: An empirical analysis of the stakeholder approach to corporate governance. Business and Society, 53(3) (pp. 414-439).

Belikov I., Verbitskyy V. et al. (2007) Strategia razvitia i korporativnoye upravlenie srednikh kompanii [Development strategy and corporate governance of medium-sized companies]. Zhurnal korporativnoie upravlenie (Corporate governance), (3) (pp. 50-57) [in Russian]

Bianco M., Ciavarella A. et al. (2015). Women on corporate board in Italy: The role of family connection. Corporate governance, 23(2) (pp. 129-144)

Bocharova I.Y. (2014). Development of corporate governance: The role of the board of directors. Actual Problems of Economics, 159(9) (pp. 171-179)

Braendle U.C. (2015) New corporate governance norms for Russia - What will change? Corporate Board: Role, Duties and Composition, 11(1), 21-29.

Briachak I. (2010) Integrirovannye korporativnye struktury v rossiiskoi promyshlennosti (Integrated corporate structures in the Russian industry). Ekonomicheskiye nauky (Economic sciences), (12) (pp. 152-157) [in Russian]

Bruno S. (2015) Legal rules, Shareholders and corporate governance. The European shareholders' rights directive and its impact on corporate governance of Italian listed companies: The Telecom S.p.a. case. Corporate Ownership and Control, 12(2CONT1) (pp. 401-415)

Chen Y., Li W. et al. (2015) Cumulative voting: Investor Protection or Antitakeover? Evidence from Family Firms in China. Corporate Governance, 23(3) (pp.234-248)

Col B., Errunza V. (2015) Corporate governance and state expropriation risk, Journal of Corporate Finance, (33) (pp. 71-84)

Dementieva A. (2011). Modeli korporativnogo upravlenia v usloviakh globalizatsii: monographia [Corporate governance models in the conditions of globalization: monograph]. - Moscow: Moscow State Institute of International Relations [in Russian]

Dimov O. (2012) Formirovanie mekhanizma adaptatsii promyshlennykh korporatsii k vozdeistviu vneshnei sredy [Forming a mechanism for adapting industrial corporations to the environmental effect]. - Orenburg: Orenburg State University [in Russian]

Dolan S., Garsia S. (2008) Upravlenie na osnove tsennostei. Korporativnoe rukovodstvo po vyzhivaniu, uspeshnoi zhiznedeiatelnosti i umeniu zarabatyvat dengi v XXI veke [Value-based governance. Corporate guidance for survival, successful activity and moneyearning skills in the $21^{\text {st }}$ century]. - Moscow: Pretext [in Russian]

Drago C., Millo F. et al. (2015) Corporate governance reforms, interlocking directorship and company performance in Italy. International Review of Law and Economic, (41) (pp. 38-49)

Du M., Chen S. et al. (2014) Corporate governance: Institutional arrangement or market choice? An analytical framework of simultaneous equations based on causal relationship. Chinese Management Studies, 8(4) (pp. 717-744)

Ducassy I., Montandrau S. (2015) Corporate social performance, ownership structure and corporate governance in France. Research in International Business and Finance, (34) (pp. 383-396)

Elbadry A., Gounopoulos D. et al. (2015) Governance quality and information asymmetry. Financial Markets, Institutions and Instruments, 24(2-3) (pp. 127-157)

Findlay M. (2014) Corporate sociability: Analyzing motivation for collaborative regulation. Administration and Society, 46(6) (pp. 339370)

Fox M.B. (2014) Ongoing issues in Russian corporate governance. Columbia Journal of Transitional Law, 52(2) (pp. 435-463)

Ivanova E. (2012). Razvitie korporativnogo upravlenia v promyshlennosti Rossii: teoria, metodologia, praktika [Corporate governance development in Russian industry: theory, methodology and practice]. - Rostov-on-Don: Rostov State University [in Russian]

Kapustkina E., Sinyutin M. et al. (2008) A note on entrepreneurial trust in Saint-Petersburg Region of contemporary Russia. International Journal of Entrepreneurship and Small Business, 6(1) (pp. 94-102)

Kapustkina E.V. (2008) The system of business financing in Russia: The gender aspect. International Journal of Entrepreneurship and Small Business, 5(3-4 (pp. 297-317)

Kirdina S. (2005). Teoria institutsionalnykh matrits (Primer rossiiskogo institutsionalizma). Postsovetskii institutsionalizm [Theory of institutional matrixes (An example of Russian institutionalism). Post-soviet institutionalism]. - Donetsk: Kashtan.

Kleiner G. (2011) Menedzheralnaia revolutsia i instituty [Managerial revolution and institutes]. Institutsionalnaia ekonomika: razvitie, prepodavanie, prilozhenia (Institutional economy: development, teaching, and application). http://www. kleiner.ru/arpab/mened_ 2011.html [in Russian]

Lai J.-H., Chen L.-Y. (2014) The valuation effect of corporate governance on stakeholder wealth: Evidence from strategic alliances. International Review of Economics and Finance, (32) (pp. 17-131)

Lidery srednego biznesa [Leaders of middle-sized business] (2013) Expert RA Rating Agency. Retrieved from http://raexpert.ru/project/ gazeli/2013/resume/ [in Russian] 
Lin P.T., Li B. et al. (2015) The relationship between corporate governance and community engagement: Evidence from the Australian mining companies. Resources Policy, (43) (pp. 28-39)

Malinina T.B., Dadianova I.B. et al. (2015) Information presentation of professional structure of Russian society in mass media. Review of European Studies, 7(9) (pp. 41-59)

Mitchell R.K., Agle B.R. et al. (1997) Towards the theory of stakeholder identification and salience: defining the principle of who and what really counts. Academy of Management Review, 122(4) (pp. 853-886)

Natsionalnyi doklad po korporativnomu upravleniu [National report on corporate governance]. (2014) Issue У11, - Moscow. [in Russian]

Nhung L.T.P., Okuda H. (2015) Effects of state ownership on companies' capital structure and profitability: Estimation analysis before and after the Lehman shock. Journal of Asian Economics, (38) (pp. 64-78)

Norman U., Hit G. (2006) Teoria interesov, korporativnoie upravlenie i gosudarstvennyi menedzhment. Chemu mozhet nauchit v postenronovskuu epokhu istoria gosudarstvennykh predpriatii? [The theory of interests, corporate governance and governmental management. What can be learned in the post-enron era from the history of governmental companies?] Ekonomicheskaia politika (Economic policy), (4) (pp. 73-97) [in Russian]

Pfang R. (2015) Management in the catholic church: Corporate governance. Journal of Management, Spirituality and Religion, 12(1) (pp. 38-58)

Polterovich V. (2009) Problema formirovania natsionalnoi innovatsionnoi sistemy [The issue of forming a national innovation system]. Ekonomika i matematicheskie metody (Economy and mathematic techniques), (2) (pp. 3-18) [in Russian]

Prison M., Turnbull S. The future of corporate governance: Network governance - A lesson from the financial crisis. Human Systems Management, 34(1) (pp. 81-89)

Radygin A. (ed.) (2007) Vneshnie mekhanizmy korporativnogo upravlenia: nekotorye prikladnye problemy [External mechanisms of corporate governance: some applied issues]. - Moscow: IEPP [in Russian]

Radygin A. (ed.) (2009) Vnutrennie mekhanizmy korporativnogo upravlenia: nekotorye prikladnye problemy [Internal mechanisms of corporate governance: some applied issues]. - Moscow: DELO [in Russian]

Rees W., Rodionova T. (2015) The influence of family ownership on corporate social responsibility: An international analysis of publicity listed companies. Corporate Governance, 23(3) (pp. 184-202)

Rossi M., Nerino M et al. (2015) Corporate governance and financial performance of Italian listed firms. The results of an empirical research. Corporate Ownership and Control, 12(2CONT5) (pp. 628-643)

Rubtcova M., Pavenkov O. et al. (2015) Deprofessionalisation as a performance management dysfunction: The case of inclusive education teachers in Russia. Asian Social Science, 11(18) (pp. 339-349)

Rubtcova M., Pavenkov O. et al. (2015) The language of altruism: Corpus-based conceptualization of social category for management sociology. Asian Social Science, 11(13) (pp. 289-297)

Rubtsova M.V. (2007) Manageability: Sociological theoretical analysis of notions. Sotsiologicheskie Issledovaniya, (12) (pp. 32-38)

Rubtsova M.V. (2011) Governmentability in interaction of subjects. Traditional and new practice. Sotsiologicheskie Issledovaniya, (2) (pp. 46-53)

Ruzhanskaia L. (2010) Model rossiiskoi korporatsii v usloviakh institutsionalnykh transformatsii [The model of Russian corporation in the conditions of institutional transformations]. - Saint-Petersburg: Saint-Petersburg State University [in Russian]

Sabatier M. (2015) A women's boom in the boardroom: Effects on performance? Applied Economics, 47(26) (pp. 2717-2727)

Schmid T., Ampenberger M. et al. (2015) Family firm heterogeneity and corporate policy: Evidence from diversification decision. Corporate Governance, 23(3) (pp. 285-302)

Shumeiko M. (2011) Vliyanie sotsiokulturnykh faktorov na formirovanie rossiiskogo korporativnogo upravlenia (The effect of social and cultural factors on the formation of Russian corporate governance). - Moscow: Moscow State University [in Russian]

Solomon, J. (2010) Corporate Governance and Accountability. - UK: John Wiley \& Sons Ltd, The Atrium

Spraggon M., Bodolica V. (2015) Trust, authentic pride, and moral reasoning: A unified framework of relational governance and emotional self-regulation. Business Ethics, 24(3) (pp. 297-314)

Tan X., Ding Z. (2015) Uncertainty, corporate governance and investor protection. International Journal of Smart Home. 9(4) (pp. 47-56)

Tarando E.E., Mishalchenko Y.V. et al. (2015) Realization of copyright in Russia in the sphere of scientific articles: The experience of applied sociological analysis. Review of European Studies, 7(3) (pp. 113-123)

Thibeault I.V., Prichina O.S. et al. (2015) Cognitive Russian modeling in the system of corporate governance. Mediterranean Journal of Social Science, 6(2) (pp. 442-452)

Tikhonova V. (2011) Sovershenstvovanie printsipov korporativnogo upravlenia v oblasti vzaimodeistvia grupp steikkholderov (Improving the principles of corporate governance in the area of interaction of stakeholder groups). Voprosy ekonomiki i prava (Issues of economy and law), (6) (pp. 93-96) [in Russian]

Ustyuzhanina E., Evsyukov S. et at. (2011) Sostoianie i perspektivy razvitia korporativnogo sektora rossiiskoi ekonomiki [Condition and development perspectives of a corporate sector of the Russian economy]. - Moscow: Central Economic Mathematical Institute of the Russian Academy of Sciences [in Russian]

Uysal N., Tsetsura K. (2015) Corporate governance on stakeholders issue: Shareholders activism as a guiding force. Journal of Public Affairs, 15(2) (pp. 210-219)

Van Essen M., Strike V.M. et al. (2015) The resilient family firm: Stakeholder outcomes and institutional effects. Corporate Governance, 23(3) (pp. 167-183)

Verbitskyy V. (2014) Korporativnoe upravlenie kak instrsument kreditovania sredneho biznesa [Corporate governance as a crediting tool 
for middle-sized business]. Rynok tsennykh bumag (Securities market), (5) (pp. 94-105) [in Russian] Veselov Yu.V. (2015) Routine practices of nutrition. Sotsiologicheskie Issledovaniya, (1) (pp. 95-104) Vesnin V., Kafidov V. (2013). Korporativnoie upravlenie [Corporate governance]. - Moscow: INFRA-M.

Williamson O. (1996) Ekonomicheskie instituty kapitalizma: Firmy, rynki, 'otnoshencheskaia' kontraktatsia [Economic institutes of capitalism: firms, markets, 'relational' contraction]. -Saint-Petersburg: Lenizdat; CEV Press [in Russian]

Yakovlev A., Simachev Yu. et al. (2010) Korporativnoie upravlenie v rossiiskikh kompaniakh: do i posle krizisa [Corporate governance at Russian Companies: pre- and post-crisis]. - Moscow: Publishing House GU-vShEn [in Russian] 